The University of Southern Mississippi

The Aquila Digital Community

Faculty Publications

5-1-2015

\title{
Molecular and Phenotypic Characterization of Methicillin- Resistant Staphylococcus aureus Isolates Causing Bacteremia At a Major Hospital in Southern Mississippi
}

\author{
Dhritiman Samanta \\ University of Southern Mississippi, dhritiman.samanta@eagles.usm.edu \\ Justin Batte \\ University of Southern Mississippi, justin.batte@usm.edu \\ Stephanie N. Brown \\ Forrest General Hospital \\ Angela G. Crosby \\ Mississippi State Department of Health \\ Luis A. Marcos \\ Forrest General Hospital
}

See next page for additional authors

Follow this and additional works at: https://aquila.usm.edu/fac_pubs

Part of the Biology Commons

\section{Recommended Citation}

Samanta, D., Batte, J., Brown, S. N., Crosby, A. G., Marcos, L. A., Elasri, M. O. (2015). Molecular and Phenotypic Characterization of Methicillin-Resistant Staphylococcus aureus Isolates Causing Bacteremia At a Major Hospital in Southern Mississippi. American Journal of Infection Control, 43(5), 540-542. Available at: https://aquila.usm.edu/fac_pubs/15144

This Article is brought to you for free and open access by The Aquila Digital Community. It has been accepted for inclusion in Faculty Publications by an authorized administrator of The Aquila Digital Community. For more information, please contact Joshua.Cromwell@usm.edu. 
Authors

Dhritiman Samanta, Justin Batte, Stephanie N. Brown, Angela G. Crosby, Luis A. Marcos, and Mohamed 0. Elasri

This article is available at The Aquila Digital Community: https://aquila.usm.edu/fac_pubs/15144 
Published in final edited form as:

Am J Infect Control. 2015 May 1; 43(5): 540-542. doi:10.1016/j.ajic.2015.01.023.

\title{
Molecular and phenotypic characterization of methicillin- resistant Staphylococcus aureus isolates causing bacteremia at a major hospital in Southern Mississippi
}

\author{
Dhritiman Samanta, M.Sc ${ }^{a}$, Justin L. Batte, B.S. ${ }^{a}$, Stephanie N. Brown, BSMT(ASCP), MPH ${ }^{b}$, \\ Angela G. Crosby, B.S. ${ }^{c}$, Luis A. Marcos, MD, MPH ${ }^{b}$, and Mohamed O. Elasri, Ph.D. ${ }^{a}{ }^{*}$ \\ aThe University of Southern Mississippi, 118 College Drive, Hattiesburg, MS 39406, USA \\ bForrest General Hospital, 6051 U.S. 49, Hattiesburg, MS 39401, USA \\ 'Mississippi State Department of Health Laboratory, 570 East Woodrow Wilson Drive, Jackson, \\ MS 39216, USA
}

\begin{abstract}
Staphylococcus aureus is the predominant cause of bacteremia worldwide. We assessed the molecular epidemiology and antibiotic resistance of MRSA isolates causing bacteremia in Southern Mississippi. Diverse genetic backgrounds in terms of SCCmec, PFGE, and MLST types of MRSA were identified as causing bacteremia in Mississippi. A strong association of Panton Valentine Leukocidin (PVL) genes with elevated vancomycin MIC is one of the important findings of our study.
\end{abstract}

\author{
Keywords \\ MRSA; vancomycin; PVL; epidemiology; Staphylococcus
}

\section{Background}

\begin{abstract}
Staphylococcus aureus is a major human pathogen responsible for both community and healthcare-associated infections. In the United States, pulsed field type USA300 has been the dominant strain causing methicillin resistant Staphylococcus aureus (MRSA) infections in community settings. Although USA100 used to be the predominant type causing clinical bacteremia, some reported that USA300 is becoming more dominant even in healthcare settings [1]. Notably, in that study, no data was reported from Mississippi. This gap in the epidemiological information led to this study.
\end{abstract}

\footnotetext{
(c) 2015 by the Association for Professionals in Infection Control and Epidemiology, Inc. Published by Elsevier Inc.

*Corresponding author. 118 College Drive \#5018, Hattiesburg, MS, USA 39406 mohamed.elasri@ usm.edu, Telephone: +1 601266 6916 (Office).

Publisher's Disclaimer: This is a PDF file of an unedited manuscript that has been accepted for publication. As a service to our customers we are providing this early version of the manuscript. The manuscript will undergo copyediting, typesetting, and review of the resulting proof before it is published in its final citable form. Please note that during the production process errors may be discovered which could affect the content, and all legal disclaimers that apply to the journal pertain.
} 
Vancomycin has been the most successful antibiotic against MRSA infections. However, continued use of vancomycin leads to emergence of resistance [2-5]. Hence, for effective treatment with vancomycin, early detection of risk factors that may be associated with the increased resistance is important.

We genotyped 30 randomly chosen bacteremia-causing isolates by molecular methods, assessed their antibiotic resistance, and analyzed the association of risk factors with the elevated vancomycin MIC in certain strains.

\section{Methods}

The Institutional Review Board of The University of Southern Mississippi and the Forrest General Hospital approved this study. Between March 2013 and February 2014, 322 MRSA isolates were collected from a large hospital in Southern Mississippi. From these, 30 blood isolates were randomly selected for this study.

The presence of mecA, Panton - Valentine leukocidin genes (PVL) and hemolysin gamma ( $h l g$ ) were tested by PCR using chromosomal DNA prepared from the isolates. Pulsed field gel electrophoresis (PFGE), Multi-locus sequence typing (MLST), and SCCmec typings were performed as described elsewhere [6-8].

Isolates were tested for susceptibility to vancomycin, oxacillin, erythromycin, clindamycin, rifampin, amoxicillin-clavulanic acid, trimethoprim-sulfamethoxazole, and linezolid using the broth microdilution method [9]. The medical records of all the patients were reviewed for potential risk factors. These factors were binary coded in SPSS. The association between risk factors and vancomycin MIC $>1 \mu \mathrm{g} / \mathrm{ml}$ was analyzed by Fisher's exact test. The factors that displayed a $P$ value $<0.2$ were included in logistic regression to determine the odds ratio (OR).

\section{Results}

The MRSA isolates belonged to two major clusters in PFGE, designated A and B (Figure 1). Cluster A was composed of isolates with USA100 and USA800 types, whereas Cluster B was composed of USA300 and USA700 type isolates. USA300 was found to be the most common (40\%). USA100, 700 and 800 accounted for 23.3, 20 and $13.3 \%$ of the isolates respectively. $40 \%$ of the isolates belonged to ST5, constituting the largest group. ST8, ST72 and ST100 were found in 37, 20 and 3\% of the isolates respectively. SCCmec type IV was found in $67 \%$ of the isolates. All but one of the USA300 isolates were mec type IV. USA100 isolates were found to exclusively possess SCCmec type II, which accounted for $29 \%$ of the blood isolates.

All USA300 strains were found to be PVL positive. USA100 strains were mostly found to be PVL negative, indicating HA-MRSA isolates (17\%). All isolates were resistant to oxacillin and amoxicillin-clavulanic acid. 93\% were resistant to erythromycin followed by $30 \%$ resistant to clindamycin. All isolates were sensitive to vancomycin, rifampin, trimethoprim-sulfamethoxazole, and linezolid. Notably, we observed that some isolates had MIC for vancomycin higher than others. Specifically, 10 isolates had vancomycin MIC >1 
$\mu \mathrm{g} / \mathrm{ml}$ and of them, five isolates had MIC of $2 \mu \mathrm{g} / \mathrm{ml}$ (Table 1). We aimed to identify any risk factors associated with this phenomenon. Review of the medical records of the patients revealed several potential risk factors (Table 2). A univariate analysis revealed that smoking $(P=0.09)$, prior antibiotic use $(P=0.03)$, Prior hospitalization $(P=0.1)$, coming from a nursing home $(P=0.07)$, and presence of PVL in the isolate $(P=0.01)$ may be associated with vancomycin MIC $>1 \mu \mathrm{g} / \mathrm{ml}$. These factors were then included in logistic regression to determine the OR. The results are summarized in Table 2. Interestingly, presence of PVL showed OR of $12.223,95 \%$ confidence interval $1.507-32.769 ; P=0.024$. This suggests that the odds of elevated vancomycin MIC increase with presence of PVL genes in the isolate.

\section{Discussion}

Our analysis showed that the majority of bacteremia were caused by USA300-ST8-

SCCmecIV isolates. This predominance of USA300 was observed in studies done in other regions of the United States as well. The predominance of CA-MRSA over HA-MRSA in the hospital setting has been mathematically modeled by D'Agata et al. [10]. They predicted that CA-MRSA would eventually become dominant in hospitals. Our observation from the hospitalized patients confirms the predominance of USA300 isolates (CA-MRSA) in bacteremia-causing isolates in our region.

USA300 isolates are typically susceptible to clindamycin [6]. However, in this study, we found that $30 \%$ of USA300 isolates were clindamycin resistant. This supports previous observations in other studies that reported emerging resistance of USA300 isolates against clindamycin [11-14].

An important finding of our study is the strong association of the PVL genes with elevated vancomycin MIC. PVL is a leukocidin that kills human neutrophils by lysing the cell membrane. Although it is regarded as a virulence factor for CA-MRSA isolates, the role of PVL has been debated [15-19]. Any relation between PVL and vancomycin MIC has not been studied and further research is needed. Our study suggests that an early detection of PVL in an isolate may be important to make decisions about subjecting a patient to prolonged vancomycin treatment so that emergence of any vancomycin intermediate isolate can be prevented.

Identification of the factor 'coming from a nursing home' associated with elevated vancomycin MIC, suggest that some of these patients may have been colonized with MSRA during their stay in healthcare facilities. Nursing home and their staff have been described as reservoirs for MRSA and they are likely to share the same MRSA strain [20]. Thus, strict infection control measures are needed to stop the spread of MRSA to the residents and workers in nursing homes. MRSA in nursing homes can be under control by enhancing infection prevention measures such as early screening and decolonization of MRSA carriers, improving hand hygiene, and decreasing the resident:staff ratio [21] 
As most of the MRSA in this study were USA300 or community-associated MRSA, a particular area where interventions would be valuable from the public health perspective is to develop effective strategies for preventing infections outside the acute care setting.

In conclusion, to the best of our knowledge, this is the first report of systematic analysis of MRSA isolates in Mississippi. Collectively our data show the presence of both CA-MRSA and HA-MRSA isolates among bacteremia-causing MRSA in this region and that USA300 is dominant in a hospital setting, which is also an extension of a nationwide observation and mathematical prediction; however, the association of PVL genes as a risk for vancomycin MIC warrants more detailed investigation.

\section{Acknowledgments}

This work was funded by the National Institutes of Health (grant 1R15AI099922, to M.O.E.) and by the Mississippi INBRE, with an Institutional Development Award (IDeA) of the National Institute of General Medical Sciences (grant number P20GM103476).

\section{References}

1. Tenover FC, et al. Characterization of nasal and blood culture isolates of methicillin-resistant Staphylococcus aureus from patients in United States Hospitals. Antimicrob Agents Chemother. 2012; 56(3):1324-1330. [PubMed: 22155818]

2. Hiramatsu K, et al. Dissemination in Japanese hospitals of strains of Staphylococcus aureus heterogeneously resistant to vancomycin. Lancet. 1997; 350(9092):1670-1673. [PubMed: 9400512]

3. Hiramatsu K, et al. Methicillin-resistant Staphylococcus aureus clinical strain with reduced vancomycin susceptibility. J Antimicrob Chemother. 1997; 40(1):135-136. [PubMed: 9249217]

4. Sieradzki K, et al. The development of vancomycin resistance in a patient with methicillin-resistant Staphylococcus aureus infection. N Engl J Med. 1999; 340(7):517-523. [PubMed: 10021472]

5. Ploy MC, et al. First clinical isolate of vancomycin-intermediate Staphylococcus aureus in a French hospital. Lancet. 1998; 351(9110):1212. [PubMed: 9643727]

6. McDougal LK, et al. Pulsed-field gel electrophoresis typing of oxacillin-resistant Staphylococcus aureus isolates from the United States: establishing a national database. J Clin Microbiol. 2003; 41(11):5113-5120. [PubMed: 14605147]

7. Enright MC, et al. Multilocus sequence typing for characterization of methicillin-resistant and methicillin-susceptible clones of Staphylococcus aureus. J Clin Microbiol. 2000; 38(3):1008-1015. [PubMed: 10698988]

8. Ghaznavi-Rad E, et al. A simplified multiplex PCR assay for fast and easy discrimination of globally distributed staphylococcal cassette chromosome mec types in meticillin-resistant Staphylococcus aureus. J Med Microbiol. 2010; 59(Pt 10):1135-1139. [PubMed: 20616192]

9. Methods for dilution antimicrobial susceptibility tests for bacteria that grow aerobically. Approved Standard M07-A8; approved standard. Wayne, PA: Clinical and Laboratory Standards Institute; 2009.

10. D'Agata EM, et al. Modeling the invasion of community-acquired methicillin-resistant Staphylococcus aureus into hospitals. Clin Infect Dis. 2009; 48(3):274-284. [PubMed: 19137654]

11. Tenover FC. The quest to identify heterogeneously resistant vancomycin-intermediate Staphylococcus aureus strains. Int J Antimicrob Agents. 2010; 36(4):303-306. [PubMed: 20674281]

12. Han LL, et al. High frequencies of clindamycin and tetracycline resistance in methicillin-resistant Staphylococcus aureus pulsed-field type USA300 isolates collected at a Boston ambulatory health center. J Clin Microbiol. 2007; 45(4):1350-1352. [PubMed: 17287335] 
13. Diep BA, et al. Emergence of multidrug-resistant, community-associated, methicillin-resistant Staphylococcus aureus clone USA300 in men who have sex with men. Ann Intern Med. 2008; 148(4):249-257. [PubMed: 18283202]

14. McDougal LK, et al. Emergence of resistance among USA300 methicillin-resistant Staphylococcus aureus isolates causing invasive disease in the United States. Antimicrob Agents Chemother. 2010; 54(9):3804-3811. [PubMed: 20585117]

15. Voyich JM, et al. Is Panton-Valentine leukocidin the major virulence determinant in communityassociated methicillin-resistant Staphylococcus aureus disease? J Infect Dis. 2006; 194(12):17611770. [PubMed: 17109350]

16. Bubeck Wardenburg J, et al. Panton-Valentine leukocidin is not a virulence determinant in murine models of community-associated methicillin-resistant Staphylococcus aureus disease. J Infect Dis. 2008; 198(8):1166-1170. [PubMed: 18729780]

17. Labandeira-Rey M, et al. Staphylococcus aureus Panton-Valentine leukocidin causes necrotizing pneumonia. Science. 2007; 315(5815):1130-1133. [PubMed: 17234914]

18. Diep BA, et al. Contribution of Panton-Valentine leukocidin in community-associated methicillinresistant Staphylococcus aureus pathogenesis. PLoS One. 2008; 3(9):e3198. [PubMed: 18787708]

19. Hongo I, et al. Phenol-soluble modulin alpha 3 enhances the human neutrophil lysis mediated by Panton-Valentine leukocidin. J Infect Dis. 2009; 200(5):715-723. [PubMed: 19653829]

20. Budimir A, et al. Prevalence and molecular characteristics of methicillin-resistant Staphylococcus aureus strains isolated in a multicenter study of nursing home residents in Croatia. Am J Infect Control. 2014; 42(11):1197-1202. [PubMed: 25241164]

21. Chamchod F, Ruan S. Modeling the spread of methicillin-resistant Staphylococcus aureus in nursing homes for elderly. PLoS One. 2012; 7(1):e29757. [PubMed: 22238650] 
- USA300 (SCCmec IV) is predominant in Southern Mississippi

- Emerging clindamycin resistance has been observed in 30\% of the USA300 isolates

- Elevated vancomycin MIC ( $>1 \mu \mathrm{g} / \mathrm{ml})$ has been observed in some isolates

- Presence of PVL was found to be a potential risk factor to elevated vancomycin MIC 


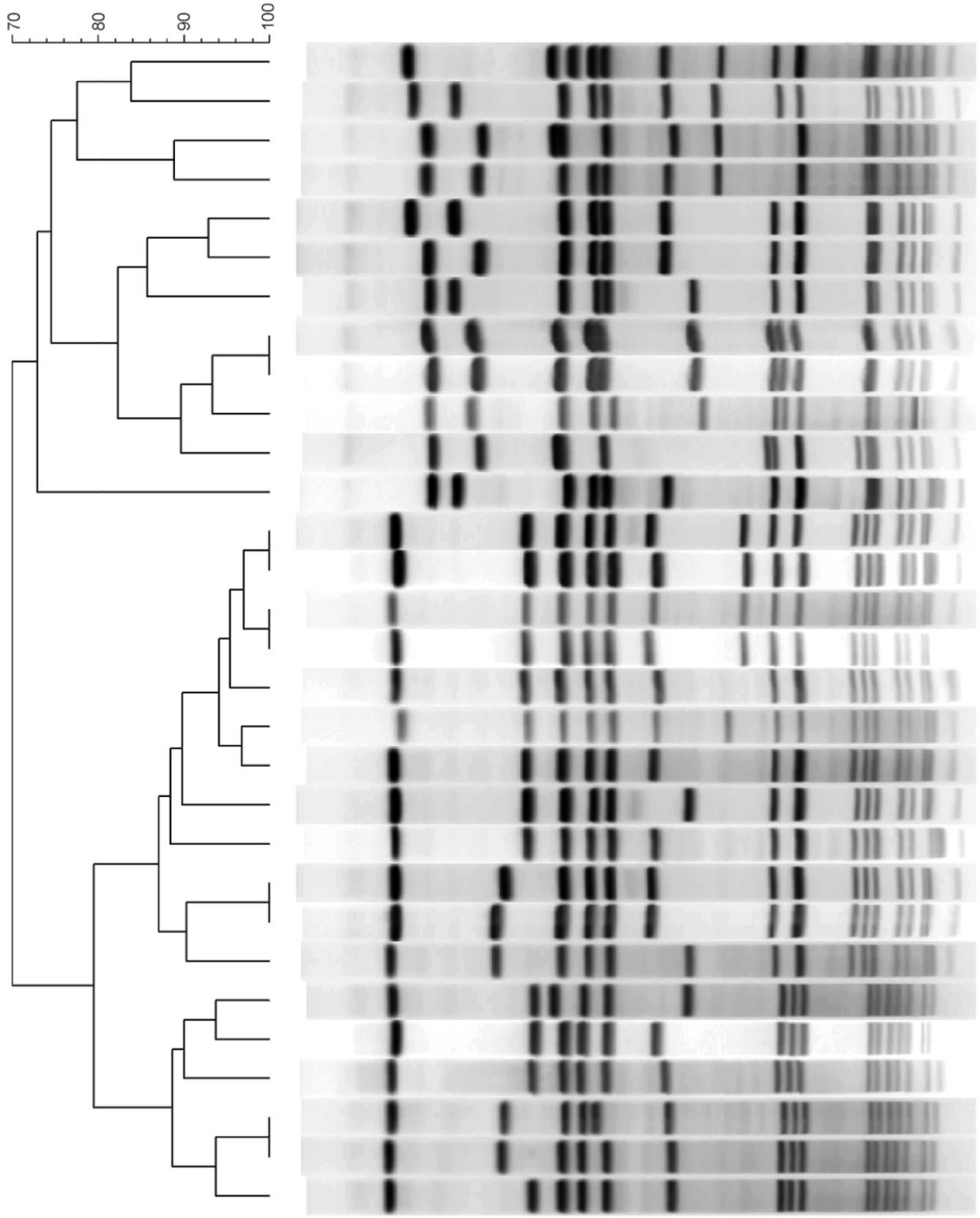

$\left.\begin{array}{lll}\text { Strain name } & \text { PFGE Type } & \text { Similarity } \\ \text { USMFG83 } & \text { USA100 } & 83.3 \\ \text { USMFG176 } & \text { USA100 } & 82.8 \\ \text { USMFG22 } & \text { USA100 } & 58.3 \\ \text { USMFG24 } & \text { USA100 } & 66.7 \\ \text { USMFG261 } & \text { USA100 } & 92.3 \\ \text { USMFG294 } & \text { USA100 } & 84.6 \\ \text { USMFG212 } & \text { USA800 } & 80.0 \\ \text { USMFG296 } & \text { USA800 } & 76.9 \\ \text { USMFG300 } & \text { USA800 } & 76.9 \\ \text { USMFG110 } & \text { USA800 } & 75.0 \\ \text { USMFG160 } & & \\ \text { USMFG133 } & \text { USA100 } & 87.0 \\ \text { USMFG297 } & \text { USA300 } & 90.3 \\ \text { USMFG302 } & \text { USA300 } & 90.3 \\ \text { USMFG100 } & \text { USA300 } & 92.9 \\ \text { USMFG301 } & \text { USA300 } & 93.3 \\ \text { USMFG143 } & \text { USA300 } & 93.3 \\ \text { USMFG13 } & \text { USA300 } & 92.9 \\ \text { USMFG96 } & \text { USA300 } & 96.3 \\ \text { USMFG295 } & \text { USA300 } & 86.7 \\ \text { USMFG118 } & \text { USA300 } & 96.3 \\ \text { USMFG226 } & \text { USA300 } & 86.7 \\ \text { USMFG299 } & \text { USA300 } & 86.7 \\ \text { USMFG26 } & \text { USA300 } & 81.5 \\ \text { USMFG95 } & \text { USA700 } & 86.7 \\ \text { USMFG306 } & \text { USA700 } & 100.0 \\ \text { USMFG141 } & \text { USA700 } & 93.3 \\ \text { USMFG14 } & \text { USA700 } & 80.0 \\ \text { USMFG50 } & \text { USA700 } & 86.7 \\ \text { USMFG52 } & \text { USA700 } & 93.3\end{array}\right\} \mathbf{B}$

Figure 1.

Pulsed-field gel electrophoresis of Blood-MRSA isolates shows that, using an $80 \%$ similarity cutoff, the isolates can be grouped into two major clusters. The cluster A is composed of USA100 and USA800 isolates whereas the cluster B is consisting USA300 and USA700 isolates. One of the isolates (USMFG160) was found to be novel in PFGE analysis, however because of its closeness to USA800 isolates, it was kept in cluster A. 


\section{Table 1}

Number of isolates possessing different MIC for vancomycin

\begin{tabular}{lc}
\hline Vancomycin MIC $(\boldsymbol{\mu g} / \mathbf{m l})$ & Number of isolates \\
\hline 0.5 & $13(43.3 \%)$ \\
1 & $7(23.3 \%)$ \\
1.5 & $5(16.6 \%)$ \\
2 & $5(16.6 \%)$ \\
\hline
\end{tabular}

竞

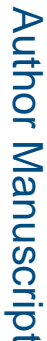


Table 2

Regression analysis between vancomycin MIC > $1 \mu \mathrm{g} / \mathrm{ml}$ and potential risk factors ${ }^{\#}$

\begin{tabular}{lccc}
\hline Variables & Odds Ratio & $\begin{array}{c}\text { 95\% Confidence } \\
\text { interval of Odds ratio }\end{array}$ & $\boldsymbol{P}$ \\
\hline PVL genes & 12.223 & $1.507-32.769$ & 0.024 \\
History of Smoking & 0.007 & $0.000-0.220$ & 0.005 \\
Prior antibiotic use & 1.160 & $0.009-2.560$ & 0.104 \\
Prior hospitalized & 1.611 & $0.123-21.122$ & 0.717 \\
Coming from a nursing home & 2.230 & $0.065-16.500$ & 0.657 \\
\hline
\end{tabular}

\# Upon reviewing patients' medical records, we identified following potential risk factors: age, sex, weight, service in first 48 hours, diabetes mellitus, chronic kidney disease, chronic heart failure, obesity, BMI, Immunosuppression, mechanical ventilation, HIV, use of injection drugs, smoking, prior antibiotic use, prior hospitalization, prior surgery, have been to long term care facility, dialysis, intravenous catheter, coming from a nursing home, positive MRSA culture, positive nasal swab, presence of PVL genes, presence of hlg gene, isolates' SCCmec type, isolates' pulsed field type, and isolates' MLST type. For crude analysis of association of these factors with vancomycin MIC > $1 \mu \mathrm{g} / \mathrm{ml}$, we performed a Fisher's exact test. The factors that showed a $P$ value lower than 0.2 , such as presence of PVL $(P=0.01)$, smoking $(P=0.09)$, prior antibiotic use $(P=$ $0.03)$, prior hospitalization $(P=0.1)$, and coming from a nursing home $(P=0.07)$ were included in the binary logistic regression analysis to determine the odds ratio. 